\title{
Manufacturing and Sensorial Acceptance of Cereal Bars Enriched with Flaxseed (Linum usitatissimum) Flour
}

\author{
Fernanda Izabel Garcia da Rocha Concenço ${ }^{1}$, Rosane Nunes de Lima Gonzales ${ }^{2}$, Marcia Vizzotto ${ }^{3}$ \\ $\&$ Leonardo Nora ${ }^{1}$ \\ ${ }^{1}$ Department of Food Science and Technology, Federal University of Pelotas, Pelotas, Brazil \\ ${ }^{2}$ Food Technology, State University of Mato Grosso do Sul, Campus Naviraí, Naviraí, Brazil \\ ${ }^{3}$ Department of Food Technology, Embrapa Clima Temperado, Pelotas, Brazil \\ Correspondence: Fernanda I. G. R. Concenço, Department of Food Science and Technology, Federal University \\ of Pelotas, Campus Universitário S/N, Capão do Leão, RS, CEP 96.160-000, Brazil. Tel: 55-53-984-590-752. \\ E-mail: fernanirocha@yahoo.com.br
}

Received: September 29, 2018

doi:10.5539/jfr.v8n1p1
Accepted: October 16, 2018 Online Published: November 8, 2018

URL: https://doi.org/10.5539/jfr.v8n1p1

\begin{abstract}
There is increasing demand from consumers for foods with functional properties. These foods, in addition to presenting adequate nutrient levels, provide beneficial health effects thus helping to prevent numerous diseases. Among the functional foods, the flaxseed (Linum usitatissimum), belonging to the family Linaceae, is of great nutritional value. This oleaginous is rich in proteins, lipids, lignans and fibers. Consumers have preference on cereal bars for being practical, healthy and with low calorie density when proper combinations of ingredients are used. This work had as objective the production and sensorial evaluation of cereal bars enriched with flaxseed flour. Two formulations, denominated S.01 and S.02, respectively added with corresponding 5\% and $10 \%$ flaxseed flour, respectively, were prepared. The physico-chemical analyzes comprised moisture and ash contents. The cereal bars were sensorially evaluated by 50 untrained testers by using the nine-point hedonic scale including attributes of flavor, texture and overall acceptance, besides intention of purchase. The averages from the sensorial evaluation were between 7 and 8 , indicating, with purchasing preference of about $90 \%$, which was considered a high acceptance rate.
\end{abstract}

Keywords: consumption, functional food, nutraceutic, processing

\section{Introduction}

At present, there is an increasing concern from the world population with food and its constituents, being the food industry encouraged to invest in healthy products. There are various forms and designations to foods that provide some type of benefit to human health, such as functional foods, nutritional products, healthy foods and, protective foods, among others (Sgarbieri \& Pacheco, 1999). According to Freitas and Moretti (2006), the term that fits better is "functional foods". It should be pointed out, however, that this definition includes only effects restricted to the promotion of health, not to the cure of diseases (Oliveira, Sivieri, Alegro \& Saad, 2002).

Flaxseed (Linum usitatissimum), originated in Asia, is among the oldest cultivated plants, being used since the beginning of civilization for human and animal consumption. It has become known worldwide as a functional food due to its beneficial effects (Alvarenga 2012; Maciel, 2006; Monego, 2009). Flaxseed is an oleaginous seed, rich in proteins, lipids and dietary fibers (Almeida, Boaventura \& Gusman-Silva, 2009). It has three components that possesses important pharmacological actions such as $\alpha$-linolenic acid, soluble and insoluble fibers and lignan, which have been evaluated in clinical trials related to breast, prostate and colon cancer, diabetes, lupus, cardiovascular, liver and kidney diseases, with favorable results regarding its benefits (Carrara, Esteves, Gomes \& Guerra, 2009). It can be consumed either as whole or ground grains, which can be added as ingredient in the preparation of bakery, meat, dairy products and sweets; and also as source of bran, gum and oil to generate other products (Bombo 2006; Villarroel, Pino \& Hazbún, 2006).

In recent decades, there have been changes in the lifestyle of the population, where eating habits have changed due to lack of time that led to preference for foods that offer greater practicality. Good examples are the cereal bars as an alternative of practical, healthy and low calorie food. Cereal bars were introduced to the market more 
than a decade ago, being a choice of healthy food which has in its composition a wide variety of ingredients with sweet and pleasant flavor, being source of vitamins, minerals, fibers, proteins and carbohydrates (Baú, Cunha, Cella, Oliveira \& Andrade, 2010; Freitas \& Moretti, 2006).

The ingredients used in the cereal bars must be suitably combined to mutually guarantee the characteristics of taste, texture and physico-chemical properties and stability, especially at the point of equilibrium of water activity. Due to the properties in its composition that act beneficially in the organism, the cereal bar is considered as a functional food (Gutkoski, Bonamigo, Teixeira \& Pedó, 2007).

Therefore, we aimed with the present work to develop and evaluate sensorially cereal bar formulations enriched with flaxseed flour, and verify its acceptability by consumers, as well as to determine some physico-chemical parameters of such formulations.

\section{Method}

The cereal bars were developed at the laboratory of Food Technology, State University of Mato Grosso do Sul, Campus at Naviraí-MS, Brazil.

\subsection{Material}

The materials used in the elaboration of the cereal bars were acquired in local stores at Naviraí-MS.

\subsection{Preparation of the Flaxseed Flour}

The flaxseed flour was obtained by grinding process with the aid of a blender.

\subsection{Elaboration of the Cereal Bars}

Two formulations of cereal bars were prepared, differing between them in the content of flaxseed flour: S.01, with $5 \%$, and S.02, with $10 \%$. The ingredients used for formulating the cereal bars are listed in Table 1.

Table 1. Ingredients used for formulation of the cereal bars (670g of expected final product).

\begin{tabular}{lll}
\hline Ingredients (g) & S.01* & S.02* \\
\hline Agglutination Syrup & & \\
\hline Crystal sugar & 197.6 & 232.6 \\
Glucose syrup & 100.0 & 100.0 \\
Honey & 35.0 & 35.0 \\
Water & 25.0 & 25.0 \\
Soybean oil & 10.5 & 10.5 \\
Soybean lecithin & 7.0 & 7.0 \\
Dry Ingredients & & \\
Rice flakes & 140.0 & 140.0 \\
Oat flakes & 140.0 & 70.0 \\
Flaxseed flour & 35.0 & 70.0 \\
Passion fruit flour & 7.0 & 7.0 \\
\hline \% and 10 \% flaxseed flour, respectively.
\end{tabular}

\subsection{Processing of the Cereal Bars}

Processing of the cereal bars was manual and started by weighing the ingredients. The agglutination syrup was prepared in a stainless steel vessel where the ingredients (sugar, glucose syrup, water, honey, vegetable fat, soy lecithin) were subjected to heating, being homogenized continuously with a spoon. The temperature was monitored with aid of a thermometer and cooking proceeded until the mixture reached $116{ }^{\circ} \mathrm{C}$, when it was interrupted.

The dry ingredients (rice flakes, oat flakes, passion fruit flour and flaxseed flour) were added to the agglutination syrup, at the temperature of about $95{ }^{\circ} \mathrm{C}$, and mixed. The mixture was casted and compacted into rectangular aluminum recipients, previously anointed with hydrogenated vegetable fat. The obtained mass was cooled to room temperature, and later the bars were cut in standard sizes of $3.5 \mathrm{~cm} \mathrm{x} 4.5 \mathrm{~cm}$, weighting $10 \mathrm{~g}$ on average. Samples were collected for the physico-chemical analysis, which were done at the same day. The cereal bars were individually packed in plastic film and stored in dry and aerated place at room temperature for one day, until the time of sensorial analysis. The flowchart (Figure 1) summarizes the procedure used in the processing of the cereal bars. 


\subsection{Physico-chemical Analysis}

Moisture and ash analyzes were performed at the Chemistry Laboratory of the State University of Mato Grosso do Sul, Campus at Naviraí-MS, Brazil.

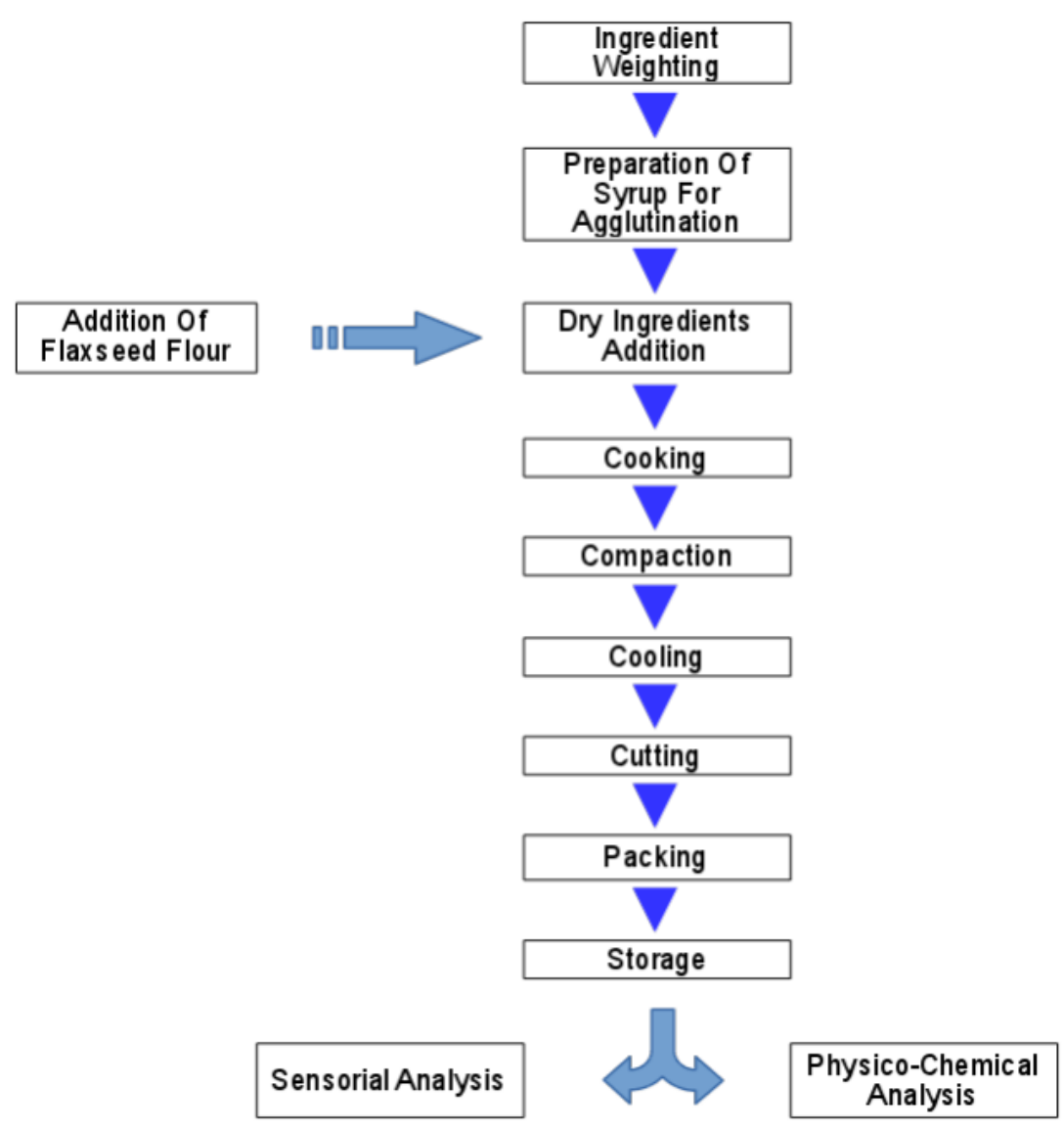

Figure 1. Schematic workflow for the processing of the cereal bar. Source: adapted from Sbardelotto (2011)

\subsection{Moisture}

Moisture content was determined according to the Adolfo Lutz Institute Standards (Adolfo Lutz Institute, 2005). The method consisted in heating samples at $130{ }^{\circ} \mathrm{C}$ in air circulating oven for the loss of free moisture, since a certain amount of water remains trapped. This method is based on the loss of volatile substances by heating. A defined amount of $2 \mathrm{~g}$ of the sample was weighted into a pre-dried, pre-weighed and tared porcelain capsule. The porcelain dish was placed into an oven at $130{ }^{\circ} \mathrm{C}$ for at least 1 hour, being later cooled into a desiccator to room temperature. The transportation of the capsules was always done with kitchen pincers to avoid passing moisture from hand to capsule. Capsules were weighted, and the process repeated until constant weight was reached. The analyzes were done in triplicates.

\subsection{Ash Content}

Determination of the ash content was performed according to Adolfo Lutz Institute Standards (Adolfo Lutz Institute, 2005). Five grams of the sample were weighted in previously dried, cooled and tared lab crucible. The sample was incinerated into a muffle at $550{ }^{\circ} \mathrm{C}$ for 5 hours, until complete removal of the charcoal to obtain a white or slightly grayish ash, which was cooled into desiccator to room temperature, being weighed and subsequently calculated the ash content. The analyzes were done in triplicates.

\subsection{Sensorial Analysis}

The cereal bar formulations were evaluated by 50 untrained testers from both genders, randomly invited to participate in the analysis. The affective acceptability test was used as methodology, by adopting a score sheet 
with a structured hedonic scale of nine points, ranging from 1 -"I disliked very much" to 9 -"I liked very much", to evaluate the attributes of flavor, texture and overall acceptance. Later, the evaluators answered a question about the certainty of purchase, ranging from 5 ("would certainly buy") to 1 ("would certainly not buy"). The results were evaluated through the frequencies assigned in the certainty scale, according to the depicted in Figure 2. Samples were identified with three random digits in full block. Fresh water at room temperature was supplied to the testers with the samples, and these were instructed to drink a little of water before tasting the next sample, in order to eliminate residual taste interference in the evaluation.

\subsection{Statistical Analysis}

The data were analyzed in five stages. From the first to the third stages, the data were explored by descriptive statistics; in the fourth and fifth stages, the data were studied by experimental statistics, being presented in the form of histograms and tables, respectively.

In the first stage of the analysis, the profile of the evaluators was determined, by classifying them by gender and by age. In the second stage, each sample was explored according to the scoring scale attributed by the evaluators for "taste", "texture" and "global acceptance". The third stage of the analysis consisted in determining the means of the scores obtained for each item, with its respective standard deviation; that is, it was possible to determine the magnitude of the scoring variation for each question attributed by the group of 50 evaluators.

\begin{tabular}{|c|c|c|c|c|c|c|}
\hline \multicolumn{7}{|c|}{ 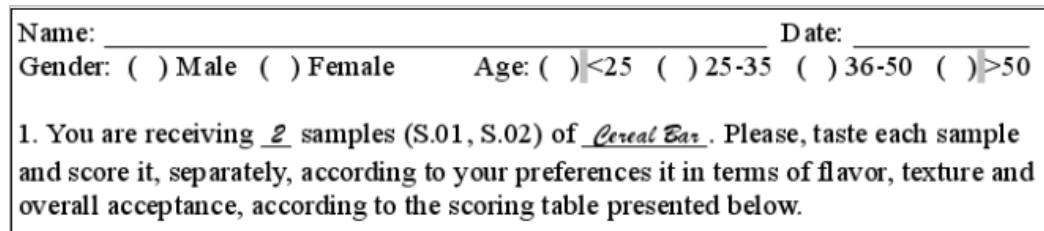 } \\
\hline \multirow{4}{*}{\begin{tabular}{|l} 
Scoring Table: \\
9 -liked very much \\
8 - liked \\
7 - moderately liked \\
6 -liked slightly \\
5 - indifferent \\
4 - disliked slightly \\
3 - moderately disliked \\
2 - disliked \\
1 - disliked very much
\end{tabular}} & \multicolumn{2}{|c|}{ Flavor } & \multicolumn{2}{|c|}{ Texture } & \multicolumn{2}{|c|}{ Acceptance } \\
\hline & S.01 & S.02 & S.01 & S.02 & S.01 & S.02 \\
\hline & & & & & & \\
\hline & & & & & & \\
\hline \multicolumn{7}{|c|}{$\begin{array}{l}\text { 2. Please indicate below the degree of certainly with which you would or would not } \\
\text { buy the sample product, supposing it would be made commercially available. }\end{array}$} \\
\hline \multicolumn{3}{|c|}{ Purchasing certainty/preference } & S.01 & & \multicolumn{2}{|c|}{ S.02 } \\
\hline \multicolumn{7}{|l|}{ 5. Would certainly buy } \\
\hline \multicolumn{7}{|l|}{ 4. Would possibly buy } \\
\hline \multicolumn{7}{|c|}{ 3. Maybe would buy, maybe not } \\
\hline \multicolumn{7}{|l|}{ 2. Would possibly not buy } \\
\hline \multicolumn{7}{|l|}{ 1. Would certainly not buy } \\
\hline \multicolumn{7}{|l|}{ Comments: } \\
\hline
\end{tabular}

Figure 2. Scoring sheet used for evaluating the sensorial acceptability and purchase preference of the cereal bar formulations. Source: Carvalho (2008)

The fourth stage of the analysis consisted in the determination of the preferred public for each sample: the average of the scores attributed by the female evaluators was compared to the score assigned by the male evaluators for the same item. The significance of this difference among audiences was measured by the T-test with Welch criteria, at $5 \%$ probability. The fifth stage of the analysis consisted in the comparison between samples for each of the items evaluated by the evaluators (taste, texture, global acceptance and certainty of purchase), through analysis of variance by the F-test at $5 \%$ probability. When the F-test indicated significance between treatments, means were compared by the Fisher's LSD test at $5 \%$ probability. All statistical analyzes and all graphs were obtained into the statistical environment " $r$ " (R Core Team, 2017). 


\section{Results}

\subsection{Physico-Chemical Analysis}

The cereal bars enriched with $5 \%$ (S.01) and $10 \%$ (S.02) flaxseed flour were analyzed for moisture and ash content. The mean values are presented in Figure 3. From the data in Figure 3, it can be observed that the cereal bars had a relatively low moisture content; S.01 (5\% flaxseed flour), presented 10.3\% moisture while S.02 (10\% flaxseed flour) presented $9.7 \%$.

The ash content observed $(1.1$ - 1.2) indicates no significant difference between the two samples of cereal bars (Figure 3). A similar result was found by Mourão (2008) who reported ash content of approximately $1.65 \%$ in cereal bars containing cashew or plums.

\subsection{Sensorial Analysis}

There was a predominance of females among the evaluators, representing $60 \%$ of the group. Evaluators ageing 25 years old or less, between 25 years old and 35 years old, between 36 years old and 50 years old and 50 years old or more comprised $48 \%, 24 \%, 24 \%$ and $4 \%$ of the total number of evaluators, respectively (Figure 4).

Figure 5 shows the distribution of the evaluator's preference for S.01 (5\% flaxseed flour) regarding flavor, texture, global acceptance and purchasing certainty / preference. Regarding flavor, $42 \%$ of the evaluators liked it $($ score $=8), 30 \%$ liked it very much (score $=9), 22 \%$ moderately liked and only $6 \%$ of them liked it slightly. For texture, $40 \%$ of the evaluators liked it, $38 \%$ liked it very much, $16 \%$ moderately liked, $4 \%$ liked it slightly and $2 \%$ neither liked nor disliked it (score $=5$ ). Overall acceptance scored higher for $42 \%$ of the evaluators, $32 \%$ liked, and $18 \%$ of respondents moderately liked it; the overall acceptance was $89.3 \%$.

Moisture

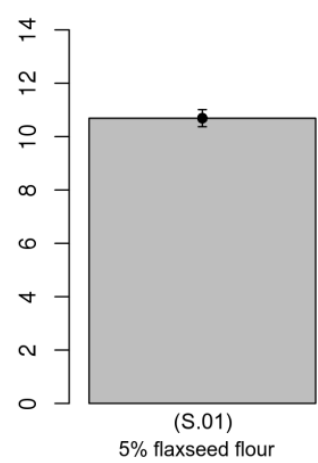

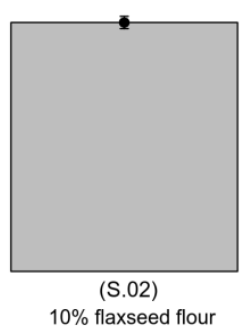

\section{Ash Content}

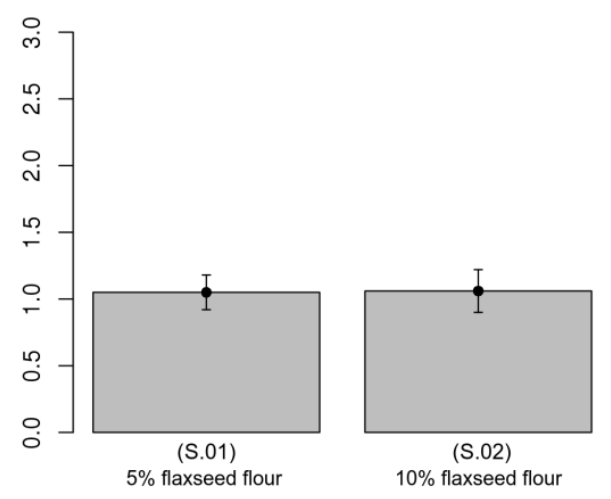

Figure 3. Moisture and ash contents (\%) in two samples of cereal bars with increasing flaxseed flour content

$$
(\mathrm{S} 01=5 \% ; \mathrm{S} 02=10 \%)
$$



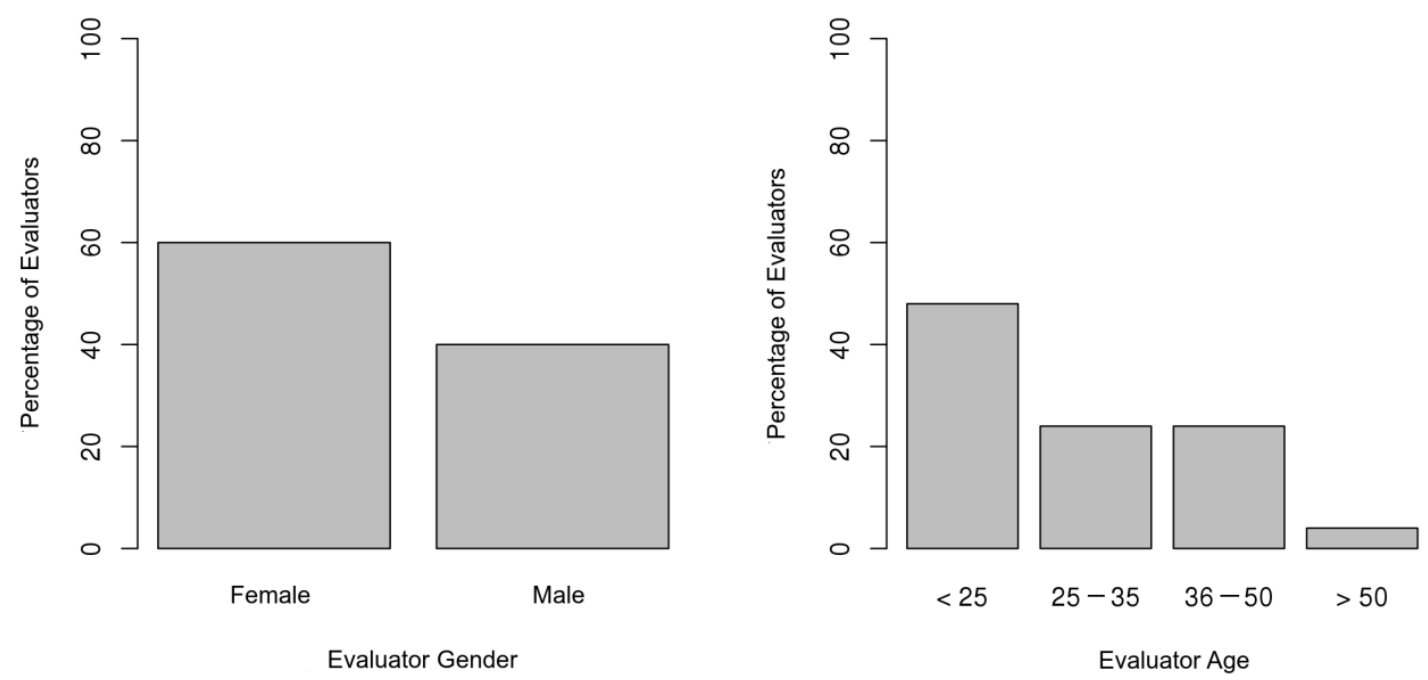

Figure 4. Distribution of evaluators in the sensorial analysis as function of gender (female, male) and age group

The results obtained on the purchasing intention indicate that $56 \%$ of the evaluators attributed score 5 (certainly would buy), and the second highest percentage was in score 4 "would possibly buy", with $26 \%$ of the answers. Thus, by adding these two groups, the product obtained about $82 \%$ buyer's preference.

Figure 6 shows the scores assigned for each item of S.01, and do not indicate a difference between the attributes "flavor," "texture" and "overall acceptance" for this formulation; the addition of $5 \%$ flaxseed flour to cereal bars did not affect either the overall acceptance or the purchasing preference.

\section{Sample 1 (S.01)}

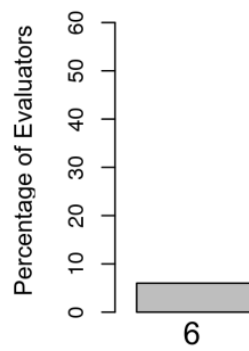

1 - disliked very much / 9 - liked very much

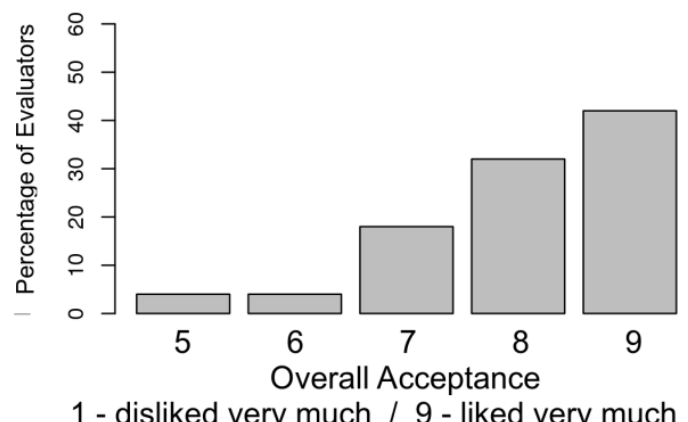

Figure 5. Evaluators distribution as function of their preference for flavor, texture, overall acceptance and purchasing preference for the formulation S.01 of cereal bar, containing $5 \%$ of flaxseed flour $(n=50)$ 
Sample 1 (S.01) - Scores
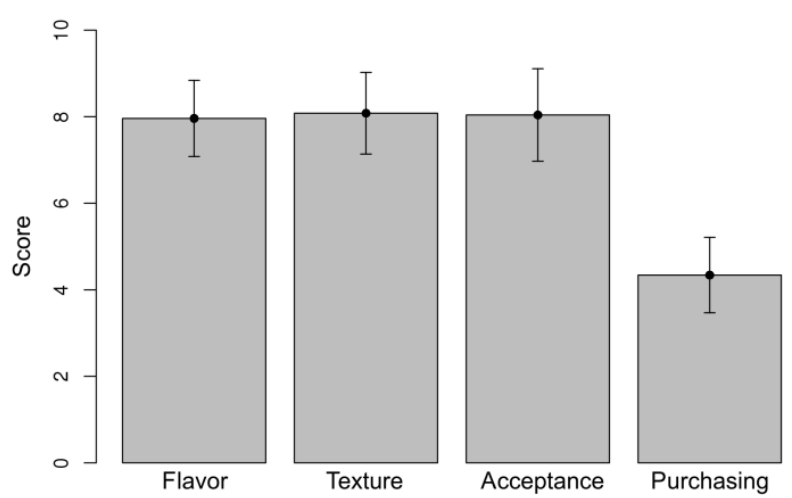

Evaluated Parameter

Figure 6. Mean scores attributed to S.01 formulation (5\% flaxseed flour) for the distinct parameters, with its respective standard deviations at $5 \%$ probability. $(n=50)$

Table 2 shows that there was no significant difference regarding the estimation of the preferential public, regarding gender, through the items evaluated in S.01 (5\% flaxseed flour in the mixture).

Figure 7 shows evaluator distribution of scores as a function of their preference for S.02 (10\% flaxseed flour in the mixture) regarding flavor, texture, overall acceptance and purchasing preference. As for flavor, the results show that $40 \%$ of the evaluators liked it (score $=8$ ), $18 \%$ liked it very much (score $=9$ ), $28 \%$ liked it moderately (score $=7$ ) and only $14 \%$ liked it slightly (score $=6$ ).

Table 2. Evaluator preference by gender according to scores attributed to each parameter on S.01 (5\% flaxseed flour)

\begin{tabular}{lllll}
\hline Parameter & Female & Male & \multicolumn{2}{l}{ prob_T } \\
\hline Flavor & 7.9 & 8.05 & 0.54 & $\mathrm{~ns}$ \\
Texture & 8.17 & 7.95 & 0.46 & $\mathrm{~ns}$ \\
Acceptance & 8.2 & 7.8 & 0.25 & $\mathrm{~ns}$ \\
Purchasing & 4.43 & 4.2 & 0.36 & $\mathrm{~ns}$ \\
\hline
\end{tabular}

* Non significant (ns) difference according to the T-test with Welch criterion, at $5 \%$ probability.

In terms of "overall acceptance" of S.02, $44 \%$ of the evaluators "liked" (score $=8$ ), $34 \%$ "liked slightly" (score $=7$ ), and $12 \%$ "liked very much" (score $=9$ ), therefore being accepted by $90 \%$ of the evaluators. According to Santana and Oliveira (2005), for a product to be considered accepted in terms of its sensory properties, it is necessary that it obtain an Acceptance Rate (AR) of at least $70 \%$. Thus, even with $10 \%$ of flaxseed flour added to the cereal bar, consumers were satisfied with the final sensorial properties of the product.

The results obtained for purchasing preference indicate that $42 \%$ of the evaluators attributed score $=5$, corresponding to "would certainly buy" and $38 \%$ of the evaluators attributed score $=4$, "would possibly buy. Another fact worth mentioning is that there was no evaluator who indicated he would not buy such a product in any formulation.

Table 3 shows that there was no significant difference regarding gender for preference to the product, for the formulation containing $10 \%$ flaxseed flour into the mixture (S.02).

Figure 8 shows the scores assigned for each item of S.02, and do not indicate a difference between the attributes "flavor," "texture" and "overall acceptance" for this formulation; similarly, to S.01 (Figure 6), the addition of $10 \%$ flaxseed flour to cereal bars (S.02) did not affect either the overall acceptance or the purchasing preference (Figure 8). 
Sample 2 (S.02)

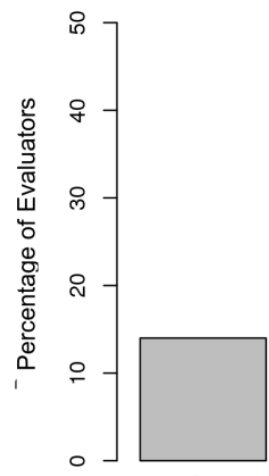

6

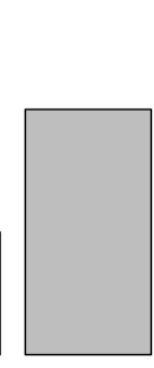

7

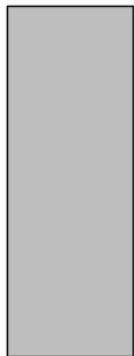

8

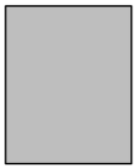

9 Flavor

1 - disliked very much / 9 - liked very much

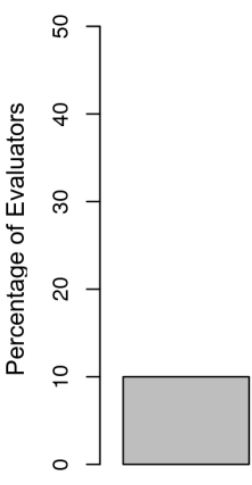

6

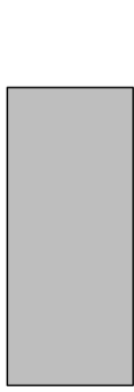

7

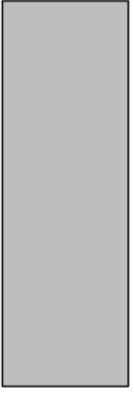

8

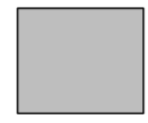

9

1 - disliked very much / 9 - liked very much

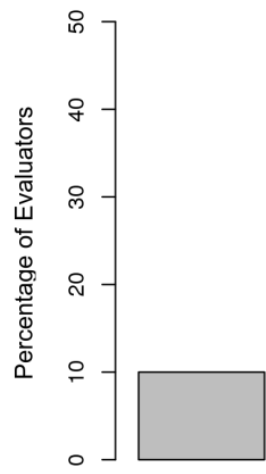

6

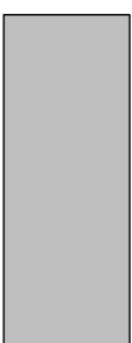

7 Texture

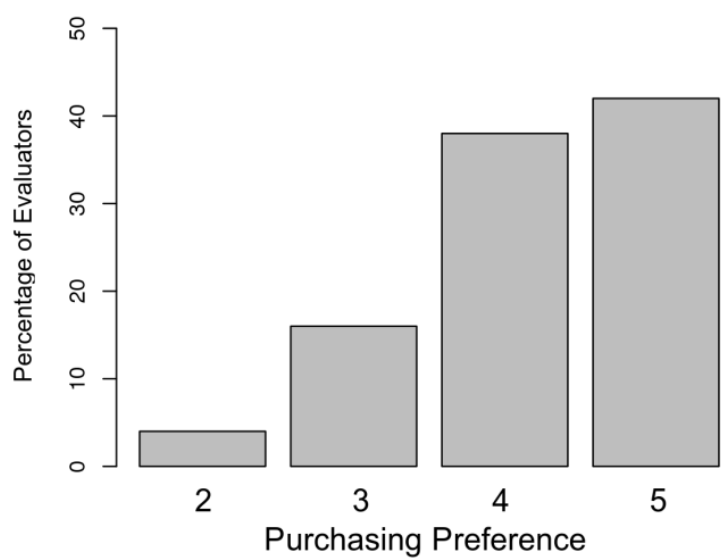

1 - certainly would not buy / 5 - certainly would buy

Figure 7. Evaluators distribution as function of their preference for flavor, texture, overall acceptance and purchasing preference for the formulation S.02 of cereal bar, containing $10 \%$ of flaxseed flour $(n=50)$

Table 3. Evaluator preference by gender according to scores attributed to each parameter on S.02 (10\% flaxseed flour)

\begin{tabular}{lllll}
\hline Parameter & Female & Male & \multicolumn{2}{l}{ prob_T } \\
\hline Flavor & 7.63 & 7.60 & 0.91 & $\mathrm{~ns}$ \\
Texture & 7.47 & 7.60 & 0.58 & $\mathrm{~ns}$ \\
Acceptance & 7.53 & 7.65 & 0.64 & $\mathrm{~ns}$ \\
Purchasing & 4.10 & 4.30 & 0.40 & $\mathrm{~ns}$ \\
\hline
\end{tabular}

* Non-significant (ns) difference according to the T-test with Welch criterion, at $5 \%$ probability. 
Sample 2 (S.02) - Scores

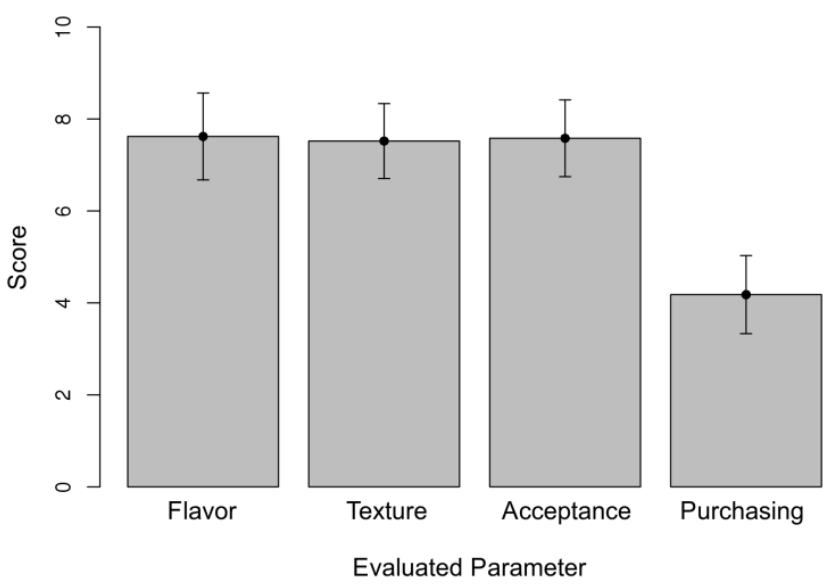

Figure 8. Mean scores attributed to S.02 formulation (10\% flaxseed flour) for the distinct parameters, with its respective standard deviations at $5 \%$ probability. $(n=50)$

The comparative preference between S.01 (5\% flaxseed flour) and S.02 (10\% flaxseed flour), according to flavor, texture, global acceptance and purchasing preference are represented in Table 4. There was no significant difference between formulations according to the F-test at $5 \%$ probability in terms of flavor and purchasing preference. Regarding texture and global acceptance, Fischer's LSD test at $5 \%$ probability indicated that S.01 was superior to S.02; thus, there was difference in consumers perception regarding flaxseed content.

Table 4. Comparative preference between S.01 and S.02 formulations, with $5 \%$ and $10 \%$ flaxseed flour into the mixture, respectively, as function of the evaluated parameter

\begin{tabular}{lllll}
\hline \multicolumn{5}{c}{ Granted Scores $^{\mathbf{1}}$} \\
\hline Sample & Flavor $^{2}$ & Texture $^{\mathbf{3}}$ & Global Accpt. $^{3}$ & Purch. Pref. $^{2}$ \\
\hline S.01 (5\%) & 7.96 & $8.08 \mathrm{a}$ & $8.04 \mathrm{a}$ & 4.34 \\
S.02 (10\%) & 7.62 & $7.52 \mathrm{~b}$ & $7.58 \mathrm{~b}$ & 4.18 \\
$\mathbf{F}_{\text {calc }}$ & $3.47^{\text {ns }}$ & $10.08^{*}$ & $5.75^{*}$ & $0.86^{\text {ns }}$ \\
CV (\%) & 11.7 & 11.3 & 12.3 & 20.2 \\
\hline
\end{tabular}

1 Granted scores were between 1 and 9 for flavor, texture and global acceptance, and between 1 and 5 for purchasing preference. For both cases, higher score means higher evaluators preference; 2 means do not differ, according to the F-test at 5\% probability; 3 means are significantly distinct, according to Fisher's LSD test at 5\% probability.

\section{Discussion}

These moisture levels (Figure 3) are satisfactory, considering that the maximum limit established by the current Brazilian legislation - Resolution RDC $\mathrm{n}^{\circ}$ 263, September 22, 2005 (Brasil, 2005), establishes that the moisture level of cereal bars should be below $15.0 \%$. According to Sarantópoulos, Oliveira and Canavesi (2001), another relevant aspect is that the moisture content is within parameters that allow the maintenance of crunchiness and at the same time does not favor microbial proliferation, since in addition to the low moisture the product also contains sugar, which contributes to the reduction of water activity. Similar moisture levels were found by Freitas and Moretti (2006), who reported a moisture content of $10.71 \%$ when analyzing high protein and vitamin cereal bars. Brito, Campos, Souza, Wakiyama and Azeredo (2004) reported lower moisture levels, about $7.63 \%$, in cereal bars.

In a study done by Mourão (2008) with cereal bar with cashew and plums added with $12.5 \%$ of flax meal, in average $21.7 \%$ of the evaluators liked it very much. For texture, $42 \%$ of the evaluators liked it, $10 \%$ liked it very much, $38 \%$ liked moderately and $10 \%$ liked it slightly. These results do not differ greatly from the ones obtained at the present study, indicating that flaxseed flour may be a viable ingredient to be added to cereal bars.

Mourão (2008) reports that $12 \%-14 \%$ of flaxseed flour added to cashew and plums cereal bars resulted in 
approximately $29 \%$ of the evaluators claiming they "maybe would buy, maybe not" (score $=3$ ). This raises the hypothesis that the acceptance by consumers of cereal bars added with flaxseed flour may depend on the other ingredients into the mixture, that is, its final taste. In this case, flaxseed flour would be suitable for addition in cereal bars of only certain flavors, but possibly, with some ingredients, the flavor of the final product could not be attractive.

For initial cereal bar formulations aiming its introduction into a new market, it would be advisable to start manufacturing cereal bars with $5 \%$ flaxseed flour into the mixture, aiming to avoid significant public rejection to the new product. As the new consumers are defined and familiar to the product, however, a formulation with $10 \%$ flaxseed flour into the mixture could be easily accepted when marketed associated to the role of functional food bars.

One should also observe that there were no industrial constraints in bars elaboration with addition of up to $10 \%$ flaxseed flour into the original cereal bar receipts. There were no issues as lack of agglutination, uninteresting remarkable taste or odor in the cereal bars or excessive hardness with addition of the flaxseed flour.

According to Carvalho et al. (2006), the sensorial analysis is an important and effective way to better understand consumer opinion and its purchasing preference regarding a new product. Considering this, it is supposed that cereal bars with flaxseed flour may be widely accepted by the public, mainly for those most concerned to a healthy diet who usually are in constant search for foods with functional properties.

\section{Conclusions}

The addition of up to $10 \%$ of flaxseed flour does not seem to cause any undesirable effect regarding technological aspects;

Both formulations (with $5 \%$ and $10 \%$ flaxseed flour into the mixture) were well evaluated in terms of sensorial aspects and purchasing preference, reaching over $80 \%$ of certainty of purchase, therefore showing their potential for commercial manufacturing.

\section{Acknowledgments}

The present study was conducted as a whole at the Food Technology Department of the State University of Mato Grosso do Sul, Navirai-MS, as part of the undergraduation requirements for diplomation of the second author. The research was funded in whole by the referred University. The other authors contributed equally in experiment conception, conduction, data analysis and manuscript writing and final correction.

\section{References}

Almeida, C. L., Boaventura, G. T., \& Guzman-Silva, M. A. (2009). A linhaça (Linum usitatissimum) como fonte de acido linolênico na formação da bainha de mielina. Nutrição, 22(5), 747-54. https://doi.org/10.1590/S1415-52732009000500015

Alvarenga, I. C. (2012). Armazenamento e forneamento de linhaça. Dissertation, Master in Food Science, Universidade Federal de Lavras, Minas Gerais, Brazil.

Baú, T. R., Cunha, M. A. A., Cella, S. M., Oliveira, A. L. J., \& Andrade, J. T. (2010). Barra alimentícia com elevado valor proteíco: formulação, caracterização e avaliação sensorial. Revista Brasileira de Tecnologia Agroindustrial, 4(1), 42-51. https://doi.org/ 10.3895/S1981-36862010000100005.

Bombo, A. J. (2006). Obtenção e caracterização nutricional de snacks de milho (Zea mays L) e Linhaça (Linum usitatissimum L.). Dissertation, Master in Public Health, Universidade de São Paulo, Brazil.

Brasil. (2005). Resolução RDC no 263, de 22 de setembro de 2005, Agência Nacional De Vigilância Sanitária Anvisa; Aprova O Regulamento Técnico Para Produtos De Cereais, Amidos, Farinhas E Farelos, Diário Oficial da União, Brasília (DF), de 23 de setembro de 2005.

Brito, I. P., Campos, J. M., Souza, T. F. L., Wakiyama, C., \& Azeredo, G. A. (2004) Elaboração e avaliação global de barra de cereais caseira. Boletim CEPPA, 22(1), 35-50.

Carrara, C. L., Esteves, A. P., Gomes, R. T., \& Guerra, L. L. (2009). Uso da semente de linhaça como nutraceutico para prevenção e tratamento da arterosclerose. Revista Eletrônica de Farmácia, 4(1), 1-9. https://doi.org/ 10.5216/ref.v6i4.8774.

Carvalho, E. A., Neto, B. A. M., Aguiar, J. C., Caldas, M. C., Cavalcanti, M. T., \& Miyaji, M. (2006). Desenvolvimento e Análise Sensorial de Sorvete de Massa Sabor Café. Jornada Nacional da Agroindústria, online. 
Carvalho, M. G. (2008). Barras de cereais com amêndoas de chichá, sapucaia, e castanha-do-gurguéia, complementadas com cascas de abacaxi. Dissertation, Master in Food Science, Universidade Federal do Ceará, Brazil.

Freitas, D. G. C., \& Moretti, R. H. (2006). Caracterização e avaliação sensorial de barra de cereais funcional de alto valor vitamínico. Ciência e Tecnologia de Alimentos, 26(2), 318-24. https://doi.org/10.1590/S0101-20612006000200014.

Gutkoski, L. C., Bonamigo, J. M. A., Teixeira, D. M. F., \& Pedó, I. (2007). Desenvolvimento de barras de cereais à base de aveia com alto teor de fibra alimentar. Ciência e Tecnologias de Alimentos, 27(2), 355-63. https://doi.org/10.1590/S0101-20612007000200025.

Instituto Adolfo Lutz. (2005). Métodos químicos e físicos para análise de alimentos, 4th ed., São Paulo.

Maciel, L. M. B. (2006). Utilização da farinha da linhaça (Linum usitatissimum L.) no processamento de biscoito tipo cracker: características físico-químicas, nutricionais e sensoriais. Dissertation, Master in Food Science, Universidade Federal do Ceará, Brazil.

Monego, M. A. (2009). Goma da linhaça (Linum usitatissimum L.) para uso como hidrocolóide na indústria alimentícia. Dissertation, Master in Food Science, Universidade Federal de Santa Maria, Brazil.

Mourão, L. H. E. (2008). Obtenção de barras de cereais de caju ameixa com alto teor de fibras processadas com ingredientes funcionais. Dissertation, Master in Food Engineering, Universidade Federal do Ceará, Brazil.

Oliveira, M. N., Sivieri, K., Alegro, J. H. A., \& Saad, S. M. I. (2002). Aspectos tecnológicos de alimentos funcionais contendo probióticos. Revista Brasileira de Ciências Farmacêuticas, 38(1), 1-21. https://doi.org/10.1590/S1516-93322002000100002.

R Core Team (2017). R: A language and environment for statistical computing. R Foundation for Statistical Computing, Vienna. http://www.R-project.org

Santana, A. F., \& Oliveira, L. F. (2005). Aproveitamento da casca de melancia (Curcubita citrullus Shrad) na produção artesanal de doces alternativos. Alimentos e Nutrição, 16(4), 363-8.

Sarantópoulos, C. I. G. L., Oliveira, L. M., \& Canavesi, E. (2001). Requisitos de conservação de alimentos em embalagens flexíveis. 1st ed., São Paulo.

Sbardelotto, J. (2011). Desenvolvimento e estudo comparativo de barras de cereais fortificadas com ferro e enriquecidas com frutooligossacarído. Graduation in Food Technology, Universidade Tecnológica Federal do Paraná, Brazil.

Sgarbieri, V. C., \& Pacheco, M. T. (1999). Alimentos funcionais fisiológicos. Brazilian Journal of Food Technology, 2(1-2), 7-9.

Villarroel, M., Pino, L., \& Hazbún, J. (2006). Desarrolho de una formulación optimizada de mousse de linaza (Linum usitatissimum L.). Archivos Latinoamericanos de Nutrición, 2(1), online.

\section{Copyrights}

Copyright for this article is retained by the author(s), with first publication rights granted to the journal.

This is an open-access article distributed under the terms and conditions of the Creative Commons Attribution license (http://creativecommons.org/licenses/by/4.0/). 